\title{
Developments in British Social Policy
}


Also by Nick Ellison

Egalitarian Thought and Labour Politics: Retreating Visions

Also by Chris Pierson

Socialism after Communism

The Modern State

Beyond the Welfare State? 


\title{
Developments in British Social Policy
}

\author{
edited by
}

Nick Ellison and Chris Pierson 
Selection, editorial matter, introductions and conclusion (C) Nick Ellison and Chris Pierson 1998

Individual chapters (in order) (C) Chris Pierson; Nick Ellison; Ruth Lister; Martin Hewitt; Paul Hirst; Noel Whiteside; Ailsa McKay; Sarah Nettleton; Stephen J. Ball; Mary Langan; Peter Malpass; Gillian Pascall; John Solomos; John Barry; David Piachaud; Michael Cahill; Laura Cram; 1998

All rights reserved. No reproduction, copy or transmission of this publication may be made without written permission.

No paragraph of this publication may be reproduced, copied or transmitted save with written permission or in accordance with the provisions of the Copyright, Designs and Patents Act 1988, or under the terms of any licence permitting limited copying issued by the Copyright Licensing Agency, 90 Tottenham Court Road, London W1P 9HE.

Any person who does any unauthorised act in relation to this publication may be liable to criminal prosecution and civil claims for damages.

The authors have asserted their rights to be identified as the authors of this work in accordance with the Copyright, Designs and Patents Act 1988.

First published 1998 by

MACMILLAN PRESS LTD

Houndmills, Basingstoke, Hampshire RG21 6XS

and London

Companies and representatives

throughout the world

ISBN 978-0-333-65921-2

ISBN 978-1-349-26638-8 (eBook)

DOI 10.1007/978-1-349-26638-8

A catalogue record for this book is available from the British Library.

This book is printed on paper suitable for recycling and made from fully managed and sustained forest sources.

$\begin{array}{llllllllll}10 & 9 & 8 & 7 & 6 & 5 & 4 & 3 & 2 & 1\end{array}$

$\begin{array}{llllllllll}07 & 06 & 05 & 04 & 03 & 02 & 01 & 00 & 99 & 98\end{array}$

Copy-edited and typeset by Povey-Edmondson

Tavistock and Rochdale, England

The editors and publishers are grateful to The Controller of Her Majesty's Stationery Office for permission to reproduce copyright material from Cm 3212, The Govermment's Expenditure Plans, 1996/7 to 1998/9. 


\section{Contents}

List of Contributors $\mathbf{x}$

Introduction Nick Ellison and Chris Pierson 1

Social policy in the postwar era 1

The causes of Keynesian economic decline 3

The conservative legacy 4

Bringing the state to market 5

Social policy in a changing world 6

Looking to the future: New Labour's social policy 11

Outline of the book 12

PART ONE - NEW PERSPECTIVES ON WELFARE THEORY Introduction 15

1 Theory in British Social Policy Chris Pierson 17

No theory please, we're British 17

'Crisis' and the new political economy of welfare 19

The coming of the new right 20

The feminist challenge 21

Gendering welfare state regimes 22

Social policy as exclusion: disability and 'race' 23

Contemporary social policy: from 'crisis' to 'structural adjustment' 24

New public management 25

Post-Fordism 26

Globalisation 27

Conclusion 29

Further reading 30

2 The Changing Politics of Social Policy Nick Ellison 31

Political parties and normative social policy 31

Changing consensus? Conservative social policy in the 1980 s and 1990s 32

Parties and manifestoes: the 1997 general election 34 
Labour's progress: Rethinking the normative base of social policy 36

New Labour, new values? 39

New social policy, old problems? 42

Conclusion 44

Further reading 45

3 New Conceptions of Citizenship Ruth Lister 46

The revival of citizenship 46

A contested concept 48

Inclusion/exclusion 52

Rearticulating citizenship 56

Further reading 60

4 Social Policy and Human Need Martin Hewitt 61

Conceptions of need 62

Understanding need in a changing society 67

Universal and particular needs 71

Conclusion 75

Further reading 77

5 Social Welfare and Associative Democracy Paul Hirst 78

Automation 79

Globalisation 81

An ageing population 84

Why is there a crisis of the welfare state? 84

An associationalist welfare state 87

Further reading 91

PART TWO - BRITISH SOCIAL POLICY IN THE 1990s

Introduction 93

6 Employment Policy Noel Whiteside 97

From full employment to flexibility: the changing policy context 99

Training and manpower policies 105

Conclusions: evaluating the flexible labour market 109

Further reading 111

7 Social Security Policy in Britain Ailsa McKay 112

Defining income maintenance policy 112

Approaches to income maintenance 115 
The design of the British system 120

Income maintenance: the reform agenda 123

Basic income maintenance versus basic income 126

Conclusion 128

Further reading 129

8 Health Policy Sarah Nettleton 130

Health policy: problems and dilemmas 130

New managerialism and the NHS 132

The internal market and the NHS 134

Purchasing primary health care 135

Health care in the community 137

Policies to improve health 137

Contemporary debates in health policy 140

Further reading 145

9 Education Policy Stephen J. Ball 146

The architecture of reform 146

Policy developments in compulsory (4-16) education 149

Policy developments in post-compulsory education 151

The outcomes and effects of change 153

Teachers' work 155

Service users 156

Conclusion: towards a new policy? 158

Further reading 159

10 The Personal Social Services Mary Langan 160

Social work on the defensive 162

The transformation of social services 165

Family support or child protection? 167

Needs-led or resource-limited? 168

Conclusion 171

Further reading 172

11 Housing Policy Peter Malpass 173

Public expenditure on housing 175

The organisation and delivery of housing services 177

Impacts on tenants and home owners 179

Conclusion 184

Further reading 186 


\section{PART THREE - CONTEMPORARY ISSUES IN BRITISH SOCIAL} POLICY

Introduction 189

12 Social Policy and Social Movements: Gender and Social Policy Gillian Pascall 191

The extent to which women's needs are not met by the welfare state 193

The nature of proposals for changes in social policy coming from the women's movement 198

Is the women's movement a new social movement? 201

The women's movement and public politics 202

Conclusion 203

Further reading 204

13 Social Policy and Social Movements: 'Race', Racism and Social Policies John Solomos 205

Background and context 207

Policy agendas and issues 210

The continuing relevance of immigration 213

What kind of future? 215

Further reading 216

14 Social Policy and Social Movements: Ecology and Social Policy John Barry 218

Ecological crisis and limits to growth 219

Challenges of the ecological critique for social policy 222

Green social policies 227

Conclusion 230

Postscript: the recent Labour government 231

Further reading 232

15 Changing Dimensions of Poverty David Piachaud 233

Poverty and social policy: changing conditions, changing assumptions 233

The diversity of approaches to poverty at present 235

The reasons for concern about poverty 238

The implications for policy 241

Further reading 245 
16 Consumerism and the Future of Social Policy Michael Cahill 247 The importance of consumption 249

Consumerism 251

The car 252

The conservatives and the car 253

Current problems 254

Changing values? 256

Consuming less 258

Further reading 259

17 UK Social Policy in European Union Context

Laura Cram 260

What is EU social policy? 261

The development of EU social policy 262

EU social policy and its impact on Britain 272

Conclusion 274

Further reading 275

Conclusion Nick Ellison and Chris Pierson 276

Change ... 276

... and continuity? 278

The future of British social policy 280

Beyond the Welfare State? 281

Bibliography 282

Index 303 


\section{List of Contributors}

Stephen J. Ball is Professor of Sociology of Education in the School of Education, King's College, London, and Director of the Centre for Public Policy Research. His books include Education Reform (1994) and Markets, Choice and Equity in Education (1995, with Sharon Gewirtz and Richard Bowe). He is Managing Editor of the Journal of Education Policy.

John Barry is Lecturer in Politics at the University of Keele. His research interests lie in the broad area of green political and moral theory and in the political economy of environmental issues, as well as contemporary social and political theory. He has published numerous articles and chapters on green politics and the normative and economic dimensions of environmental problems. He has two books forthcoming: Nature, Virtue and Progress: Rethinking Green Politics and The Environment and Social Theory.

Michael Cahill is Principal Lecturer in Social Policy at the University of Brighton. He is the author of The New Social Policy (1994) and a forthcoming book on social policy and the environment.

Laura Cram is Jean Monnet Fellow in European Public Policy at the University of Strathclyde. She is the author of a number of journal articles and book chapters on European Union social policy and of the book, PolicyMaking in the EU: Conceptual Lenses and the Integration Process (1997). She is currently writing a book on social policy in the European Union for the Macmillan European Union series.

Nick Ellison is Lecturer in Sociology and Social Policy and Deputy Dean of Social Sciences at the University of Durham. His publications include Egalitarian Thought and Labour Politics: Retreating Visions (1994), a number of articles on the Labour Party and social policy, and 'Towards a New Social Politics: Citizenship and Reflexivity in Late Modernity' (Sociology, November 1997).

Martin Hewitt teaches social policy at the University of Hertfordshire. He is the author of Welfare, Ideology and Need (1994) and several articles on social need and the future of the welfare state. $\mathrm{He}$ is presently writing a book on social policy and human nature. 
Paul Hirst is Professor of Social Theory, Birkbeck College, University of London, a member of the Political Quarterly Editorial Board and Executive of Charter 88. He is the author of Associative Democracy (1994), Globalisation in Question (1996, with Grahame Thompson) and From Statism to Pluralism (1997).

Mary Langan is Senior Lecturer in Applied Social Studies at the Open University. She is General Editor of the Routledge Social Policy Series The State of Welfare and editor of Welfare: Needs, Rights and Risks (1997).

Ruth Lister is Professor of Social Policy in the Department of Social Sciences, Loughborough University. She is a former Director of the Child Poverty Action Group and member of the Commission on Social Justice. Publications include The Exclusive Society: Citizenship and the Poor (1990) and Citizenship: Feminist Perspectives (1997).

Peter Malpass is Professor of Housing Policy at the University of the West of England, Bristol, and has been involved in research and teaching on aspects of housing in Britain since the early 1970s. His publications include Housing Policy and Practice (with Alan Murie, 5th edition, 1998), and an edited collection, Ownership, Control and Accountability: the new governance of housing (1997).

Ailsa McKay is Lecturer in the Economics Department at Glasgow Caledonian University. She is a social economist with a background in welfare rights and housing work. Her teaching and research interests are in the areas of feminist economics and the economics of the welfare state. She is currently completing her $\mathrm{PhD}$ thesis on the political economy of the basic citizens' income proposal as a strategy for the harmonisation of European social protection packages.

Sarah Nettleton is Lecturer in Social Policy at the University of York. She is the author of The Sociology of Health and Illness (1995) and a co-editor of The Sociology of Health Promotion (1995).

Gillian Pascall is Senior Lecturer in Social Policy and Administration at the University of Nottingham. She is co-author with Roger Cox of Women Returning to Higher Education (1993) and has recently published Social Policy: A New Feminist Analysis (1997). 
David Piachaud is Professor of Social Policy at the London School of Economics. He worked at the DHSS between 1968 and 1970, and subsequently in the Prime Minister's Policy Unit between 1974 and 1979. $\mathrm{He}$ is the author of numerous books and articles on poverty, social security and European social policy. Recent publications include The Price of Food (1996, with Jonathan Webb) and 'The Growth of Means-testing' in the CPAG publication, Britain Divided (1997).

Chris Pierson is Professor of Politics at the University of Nottingham. He has written extensively on the problems of social democracy and the welfare state. His most recent books are Socialism After Communism, The Modern State and Beyond the Welfare State.

John Solomos is Professor of Sociology and Social Policy at the University of Southampton. He has written widely on key aspects of race relations, including political mobilisation and the role of public policies in this field. Among his most recent books are Race and Racism in Britain and (with Les Back) Racism and Society.

Noel Whiteside is Reader in Public Policy at the University of Bristol. She has contributed numerous articles in various social policy and historical journals addressing these themes. Her books include Casual Labour (1986, with Gordon Phillips), Bad Times: unemployment in British social and political history (1991) and Government, Industry and Labour Markets in Britain and France (1997, edited with Robert Salais). 